University of Warwick institutional repository

This paper is made available online in accordance with

publisher policies. Please scroll down to view the document

itself. Please refer to the repository record for this item and our

policy information available from the repository home page for

further information.

To see the final version of this paper please visit the publisher's website. Access to the published version may require a subscription.

Author(s): Richard J. Aldrich.

Article Title: Whitehall and the Iraq War: the UK's four Intelligence Enquiries.

Year of publication: 2005

Link to published version:

http://dx.doi.org/10.3318/ISIA.2005.16.1.73

Publisher statement: None 


\title{
Whitehall and the Iraq War: The UK's Four Intelligence Enquiries
}

\author{
Richard J. Aldrich*
}

During a period of twelve months, lasting between July 2003 and July 2004, Whitehall and Westminster produced no less than four different intelligence enquiries. Each examined matters related to the Iraq War and the 'War on Terror'. Although the term 'unprecedented' is perhaps over-used, we can safely say that such an intensive period of enquiry has not occurred before in the history of the UK intelligence community. The immediate parallels seemed to be in other countries, since similar investigations into 'intelligence failure' have been in train in the United States, Israel, Australia and even Denmark. These various national enquiries have proceeded locally and largely unconscious of each other existence. However, the number of different enquiries in the UK and the extent of the media interest recalls the 'season of enquiry' that descended upon the American intelligence community in 1975 and 1976 . $^{1}$

Although the intensity of the debate about connections between intelligence and the core executive was considerable, the overall results were less than impressive. The remits of all four UK enquiries were narrowly drawn. Initially the focus was 'the dossiers' published by No.10 Downing St, one dossier in September 2002 on Iraq's Weapons of Mass Destruction (WMD), the other dossier in February 2003 on Iraq and its security services. Later, the focus shifted to the death of the unfortunate Dr David Kelly, a WMD expert working for the Ministry of Defence, and then finally to the performance of the intelligence services themselves. Public attention was concentrated upon the extent to which these enquiries might produce 'incriminating facts'. Meanwhile, wider observations and reflections about intelligence were not much in evidence. ${ }^{2}$

By mid-2003, the UK political class had convinced itself that in some sense intelligence had been 'fixed' or heavily distorted by political pressures. While there can be no doubt that intelligence was artfully selected to present what officials have called the best possible case for war', these were largely matters of over-simplification and exaggeration. While the cautious qualifications of intelligence analysts were stripped away, the basic story was not changed significantly by the publicity teams. This was more a case of 'intelligence failure'. ${ }^{3}$ We now know that most western intelligence agencies got it wrong, believing that Saddam Hussein had some existing WMD capability and thought that he was seeking to enhance it. This included not only the intelligence communities of the United States and Israel, who had long-voiced anxieties about these matters, but also the intelligence communities of countries like Germany, who enjoyed significant intelligence capability in the Middle East. Some waverers were convinced by the extent to which the German foreign intelligence service - the BND - agreed about the existence of Iraqi WMD, despite the fact that Berlin opposed military intervention. In retrospect the BND has not chosen not to probe its own record publicly. ${ }^{4}$ 
Journalists and politicians were therefore barking up the wrong tree. Although omissions and misrepresentations regarding Iraqi WMD certainly occurred along the UK's path to war, any real sleight of hand probably lay in other areas. There was misrepresentation about the ambiguous and hesitant nature of the Attorney-General's advice on the legality of war, initially described to the public as unproblematic. More importantly there was an attempt to disguise the point at which Washington decided on war with Iraq and the early moment at which the UK decided on support for Washington's policy. ${ }^{5}$ There were also issues about military operations that were conducted by the allies before the expiry for the deadline set for Iraq's compliance on WMD. ${ }^{6}$

In all these matters, UK observers were hampered by a shortage of whistleblowers. The only exception was the decision of Katherine Gunn, a translator at Government Communications Headquarters (GCHQ), the UK's signals intelligence agency, to reveal an email from the US National Security Agency, concerning the targeting of eavesdropping on the United Nations. Although arrested, the government case against her was quickly dropped when her defence team appeared likely to probe the issue of the Attorney-General's advice on war and this inadvertently steered blundering journalists back towards more promising lines of enquiry. The ambivalent text of the AttorneyGeneral's full advice was eventually leaked in February 2005. No-one else squealed. Some half a dozen intelligence officers decide to depart from the Secret Intelligence Service (SIS) because of unhappiness over Iraq and other issues related to the public exposure of intelligence at a time when that service has been re-engaging staff aged over sixty-five. However, these individuals did not speak publicly. Some went to jobs in the private sector and others were allowed to move sideways into alternative roles around Whitehall. Every effort was made to accommodate them. ${ }^{7}$

The obsession with the idea of political interference in intelligence, rather than the issue of intelligence performance, is certainly one reason why the more nuanced aspects of this remarkable year of enquiries have been overlooked. However, matters were also made difficult by the nature of the four enquiries themselves, which were all problematic in different respects. The first enquiry by the Parliamentary Select Committee on Foreign Affairs, reporting in July 2003, was remarkably politicised. The second enquiry by the Intelligence and Security Committee, reporting in September 2003, placed a narrow interpretation on a narrow remit. In January 2004, a third enquiry chaired by Lord Hutton into the death of Dr David Kelly reported. Although delivering much classified material into the public domain it was not formally focused on intelligence. A final enquiry into intelligence and WMD, chaired by Lord Butler, reported in July 2004. Although this was seemingly the most important, it was carefully steered away from issues of how intelligence connected with high-level decisions. Moreover, the chairs of the various enquiries were open to ingenious argument about the need for secrecy to override accountability.

Notwithstanding this, these enquiries generated fascinating material. Imperfect as they are, they tell us much about the current UK intelligence system. This short essay attempts to review these four enquiries in turn, ignoring the vexed matters of probity and 
propriety. Instead it asks what insights into UK intelligence we might divine from each one.

\section{The Parliamentary Select Committee on Foreign Affairs (FAC)}

The first enquiry was launched by the House of Commons Select Committee on Foreign Affairs, chaired by the stalwart Labour MP, Donald Anderson. ${ }^{8}$ Often referred to as the FAC enquiry, it was no stranger to issues of WMD, counter-terrorism and even perhaps intelligence, having considered these in several previous reports. ${ }^{9}$ Its purpose in this enquiry was to establish whether the Foreign and Commonwealth Office (FCO), within the framework of government as a whole, presented 'accurate and complete information' to Parliament in the run up to war, especially with regard to WMD. ${ }^{10}$

The FAC enquiry showed that the decision to release intelligence material to the public in the form of dossiers which had been honed by the No.10 publicity machine was an important factor, perhaps the key factor, in determining how it was received. Pre-existing relations between Fleet Street and the No.10 press machine were already unhappy. After examining the first dossier produced on Iraqi WMD in September 2002, many Whitehall journalists leapt to the conclusion that the Joint Intelligence Committee (JIC) had been under strong political pressure to change its line. One of the most interesting aspects of the FAC enquiry was the manner in which it revealed the phenomena of 'Groupthink' in several places. The term 'Groupthink' has been widely used with regard to intelligence on Iraq and other intelligence failures, but it applied no less to the gentlemen of the press. On rather limited evidence they 'assessed' that there had been political meddling. The furore generated by public accusation and counter-accusation eventually resulted in the resignation of the BBC Director-General, Greg Dyke. ${ }^{11}$

The FAC enquiry came to right conclusion. It asserted that on the evidence, Alistair Campbell 'did not exert or seek to exert improper influence' on the drafting of the September 2002 dossier on WMD. They also concluded that the claims made in the September dossier were probably 'well founded' on the basis of the intelligence then available, albeit the emphasis given to some particular facts was peculiar. In short 'allegations of politically inspired meddling' could not be established. ${ }^{12}$ They correctly observed that the International Institute for Strategic Studies in London had produced a report on Iraqi WMD shortly before the government dossier of September 2002 and had come to much the same conclusions. ${ }^{13}$

Journalists were not the only profession vulnerable to 'Groupthink'. In reality, almost all intelligence analysts, including those who had been associated with UNSCOM and UNMOVIC, believed that Iraq still had some WMD capability. ${ }^{14}$ In fairness, not all believed that the programme had been much enhanced and many were of the view that Iraq's activities did not constitute a threat to the UK, or warrant military intervention. However, the spectrum of opinion was delimited by a reluctance to question conventional wisdom. There was a systemic belief - almost an ideological conviction - that all militarist dictators wish to acquire WMD and that they are all working busily to acquire 
them. This belief was so entrenched that the possibilty that Iraq had no WMD was not really considered. In other words, a lack of current evidence of WMD could not simply mean that there were no WMD. All were wrong to a greater or a lesser degree.

What FAC also showed was that the tendency to believe that Saddam had 'something' was reinforced by other factors. First, Iraq's deliberate obstruction of the weapons inspectors throughout the 1990s, and second, the fact that the western intelligence agencies got things in Iraq wrong in the past. In 1991 they not only failed to spot the invasion they also underestimated Saddam's strategic weapons programme. Although over a decade had intervened between 1991 and the dossier of September 2002, it is important to remember that analysts (like Dr David Kelly) often spend their entire career in this highly specialist field. Those who underestimated Iraq's WMD in 1991 were the same people who were doing the overestimating in 2002. Understandably perhaps, they did to wish to have egg on face a second time. ${ }^{15}$

Although the FAC enquiry found it hard to uncover specific detail on WMD intelligence, relying on off the record briefings, it scored some success in examining a later 'dossier', produced in February 2003 concerning Saddam's mendacious security apparatus. ${ }^{16}$ The dossier said little about its origins other than the fact that it was informed by a variety of sources including 'intelligence material'. In reality it proved to have been largely plagiarised by the government's Coalition Information Centre (CIC) from three articles by Ibrahim al-Marashi, a Research Associate at the Center for Nonproliferation Studies of the Monterey Institute of International Studies and also a D.Phil student at St Antony's College Oxford. ${ }^{17}$ The government had committed several blunders here. The schoolboy-style plagiarism cast a veil of dishonesty over all the material issued in 'dossier' form. The co-option of the research student without his permission was not only unethical but also potentially exposed members of his family, who still lived in Iraq, to real risk. Moreover, the ability of academics to map the way in which key words in the dissertation had been changed, offered FAC a precise guide to how the CIC was seeking to sell its story. ${ }^{18}$ While one of the plagiarised articles comments that the Iraqi security service had a role in 'aiding opposition groups in hostile regimes', the CIC changed this in their dossier to 'supporting terrorist organisations in hostile regimes'. ${ }^{19}$ Some of the anonymous drafters from CIC were tracked down and 'dossier-ology' emerged as a new science. $^{20}$

However, wider issues were missed. Arguably, the saga of the dossiers revealed remarkable incompetence in the matter of how to put intelligence into the public domain in order to inform policy debate. The appearance of the dossiers had brought forth the comment that this had never happened before. Strictly speaking this was not the case. Although civil servants behaved as if they had never done this before, government in fact had long experience of putting intelligence material into the public domain in order to justify policy. During the Cold War, the UK ran a department of the Foreign Office, the Information Research Department, that did little else except place intelligence material into the public domain with the co-operation of journalists. A similar unit, Information Policy, existed in Northern Ireland in the early 1970s that made intelligence material available to journalists. ${ }^{21}$ SIS had made extensive material available to writers for several 
books on Soviet espionage. More broadly, over the last twenty years, much reportage on matters relating subjects such as terrorism in the Middle East was in fact provided to journalists through a well-developed system of Whitehall contacts. ${ }^{22}$

The issue of how to place intelligence material in the public domain became more important during the wars in the former Yugoslavia. Some of this related to material derived from overhead imagery assets that revealed the scale of the humanitarian disaster and pointed to war crimes, underpinning UK assertions that intervention was necessary. At a later point, similar issues occurred relating to the extent to which material gathered by GCHQ might be used to inform the activities of the International Criminal Tribunal for the former Yugoslavia. ${ }^{23}$ Overall, a great deal of experience was gained during these difficult episodes. At the end of the 1990s a classified review was conducted that sought to learn some of the intelligence lessons offered by the Yugoslavia experience. One of the major recommendations was that more thought had to be given to the issue of how intelligence material was put into the public domain to inform policy and public debate. However during 2002 and 2003 there was no evidence that this long and extensive experience had been remembered, still less applied. ${ }^{24}$

All these years of experience pointed to one thing. Journalists, are more inclined to trust spies than spin doctors. Had government chosen to release sanitised JIC papers rather than to craft dossiers containing selected JIC material, many misunderstandings would have been avoided. Ultimately, government was forced to do this anyway. The FAC enquiry had sections of a JIC report read out to them by Robin Cook. Later, the Butler report reproduced large sections of JIC reports in order to show us what we should have seen a year before. Moreover, the witnesses that were eventually paraded before the Hutton enquiry could have been made available to a parliamentary select committees at an earlier stage. Allowing the chair of the JIC, or staff from the Defence Intelligence Staff, to take a limited range of questions would have carried weight. This is not to suggest that the policy outcomes would have been different, but the public understanding of the difficulties involved in assessing WMDs would have been stronger. ${ }^{25}$

The FAC enquiry was part of a wider programme of work undertaken by the select committees of the House of Commons. Since their reform and re-invigoration in the 1980s these committees have provided one of the UK's main systems of scrutiny and accountability. They are one of the main portals for interchange between Whitehall and Westminster. ${ }^{26}$ Accordingly, the most striking aspect of the FAC report is the section dealing with co-operation - or lack of it - from the intelligence services. In Whitehallspeak the intelligence chiefs 'blanked' the FAC enquiry. The committee addressed this issue forthrightly:

We are strongly of the view that we were entitled to a greater degree of co-operation from the Government on access to witnesses and to intelligence material. Our Chairman wrote to ... the Cabinet Office Intelligence Co-ordinator; the Chairman of the Joint Intelligence Committee; the Chief of Defence Intelligence; the Head of the Secret Intelligence Service; and the Director of GCHQ. None of them replied. It was the Foreign Secretary who informed us that they would not appear. ... We asked for direct access to Joint Intelligence Committee (JIC) assessments and to relevant FCO 
papers. That was refused, although some extracts were read to us in private session. $^{27}$

The frustrations experienced by the FAC enquiry in attempting to interrogate the UK intelligence process are interesting from the point of view of accountability. In the past, many have argued that the UK's main intelligence oversight mechanism, the Intelligence and Security Committee (ISC), created in 1994, should have been set up as an additional Parliamentary Select Committee. Advocates of the select committee model for intelligence accountability have asserted that it would be more appropriate for such a committee to report to Parliament. Instead the current ISC reports to the Prime Minster and a sanitized version of its report, which replaces sensitive material with asterisks, is later released to Parliament and the public. In short, ISC is a committee of parliamentarians, but is owned by the Prime Minister. ${ }^{28}$

Significantly, FAC used its report to recommend that the ISC be reconstituted as a parliamentary select committee. ${ }^{29}$ It argued that ministers were using the existence of the ISC to block their own access to intelligence related matters that fell within legitimately the ambit of foreign affairs. However, FAC's experience contradicts its own recommendation. Although critics of the current ISC have long argued that formal select committee powers would allow the ISC to sequester documents and to compel witnesses to appear before it (ISC currently cannot do this) FAC's experience with intelligence matters suggests that these formidable select committee powers exist largely in name only. In practice, as we know from parallel American episodes, the factor that determines effectiveness is size of supporting staff. Adequate support staff are enjoyed neither by ISC, nor by any of the Parliamentary select committees. However, as we shall see, the ISC, armed with its single intrepid investigator, was at least inside the ring of secrecy. Comparing the efforts of FAC and ISC suggests that the configuration of the current ISC is more effective for its current purpose, albeit the ISC experience was not without its problems. $^{30}$

\section{The Intelligence and Security Committee (ISC)}

The ISC was set the task of enquiring into whether intelligence on Iraqi WMD was properly assessed and whether it was accurately reflected in government publications. In common with FAC they came the conclusion that the journalists had been wrong in their more specific allegations. They noted that the September 2002 dossier on Iraqi WMD had been endorsed by the JIC and that it drew on the intelligence assessments then available. They also agreed that it was not 'sexed up' by Alastair Campbell or any other member of the No.10 public relations team. ${ }^{31}$ 
Just like FAC, the need for ISC to slay the pervasive myth of gross political interference prevented it from reflecting more widely. Admittedly, poring over the minute issues of language and tracking what Alastair Campbell did and did not do, was what ISC was tasked with. However, it also has to be said that these detailed tasks came naturally to ISC, since its historic tendency has been to examine work-a-day issues of costs and efficiency rather than to think about more strategic questions. Major issues are sometimes identified by ISC, but they are rarely addressed or explored in any depth. For example, the ISC noted that it needed to report on how intelligence was placed in the public domain and on relations between the intelligence services and the media. It promised to investigate this area once the Hutton enquiry had reported in January 2004. However, in the event its 'findings' on this matter were weak, being limited to a couple of pages in its report of 2004-5. Its comments on this important subject consisted of a statement of known facts and some platitudinous observations. The issue of how government might put intelligence material into the public domain still awaits serious investigation. ${ }^{32}$

When looking at specifically at Iraqi WMD, the ISC found significant material but did seem to know what to do with it. It noted that the dossier had talked about the Iraqis 'continued' production of chemical and biological weapons in its foreword. It also identified that in reality, the UK had no information to show 'continued' production or any intelligence about the amounts of agents produced. The JIC 'did not know what had been produced and in what quantities'. In other words this was not an estimate - it was a guestimate. It had 'assessed' that production had continued to take place, but this assessing was little more than a hunch. The ISC merely observed that this 'uncertainty should have been highlighted' to give a balanced view. ${ }^{33}$

This issue was significant because it shed light on the general nature of 'estimating' biological and chemical weapons stocks. The JIC was merely doing what it had done for half a century. The evidence of several decades, and especially on the issue of chemical and biological weapons, suggests that it is almost impossible for the JIC to get it right. Whatever decade we pick we can find assertions by the JIC that these weapons are a very hard target and the only thing it was sure about was it was unlikely to get this right. $^{34}$ This problem is not about to change. It follows logically from this that any policy of pre-emption based on unqualified assertions about WMD stocks was heading for trouble. Given that the UK and the US spent much of 2002 emphasising their shift towards new strategies of pre-emption this surely deserved further comment, perhaps extensive comment. It is in the nature of things that intelligence-led policies in this area are going to be wrong much of the time. This was the sort of strategic issue that ISC should have addressed, but in practice was inclined to avoid.

In retrospect, we can also chart some odd discrepancies between the committees. Indeed, the committees themselves found comparison hard to resist. FAC had chosen to comment on ISC, while ISC responded to FAC in a special annex. On the main issue, namely did the unclassified dossier largely reflect the classified assessments, FAC and ISC were in step. However, ISC took issue with FAC's statement that the UK was 'heavily reliant' on US intelligence including material from defectors or exiles. It asserted confidently that the UK intelligence community had 'a number of their own reliable sources, including 
sources in Iraq'. ${ }^{35}$ ISC's implication that UK intelligence sources concerning Iraq were in any sense 'reliable' were roundly contradicted by the later Butler Report, which revealed SIS reporting on Iraq as notably weak. One is inclined follow Butler and not ISC on this matter. ${ }^{36}$

Both Butler and ISC disagree with FAC on the vexed issue of exiles and defectors, insisting that in contrast to Washington they played no part in the Whitehall picture. Defectors are notorious in the world of intelligence for 'gilding the lily', or exaggerating the value of the information that they carry. However, the former FCO Minister Ben Bradshaw told the FAC in April 2003 that, after the departure of the UN inspectors in 1999, the bulk of the evidence informing UK policy 'was based on intelligence, is based on defections and is based on what we know the Iraqi regime has tried to import.' Who were these defectors that Bradshaw refers to? It is likely that this is a reference to CIA material provided to Whitehall by Washington. ${ }^{37}$ A comparison of FAC, ISC and Butler reveals odd disparities and perhaps indicates the limits of the ability of ISC to probe some of these matters. Ultimately, ISC is only just inside the ring of secrecy and to an extent has to believe what it is told.

\section{The Hutton Report on Dr David Kelly (Hutton)}

Lord Hutton's report was specifically an investigation into the circumstances surrounding the death of David Kelly. Nevertheless, intelligence was woven into the fabric of its deliberations and much time was spent exploring the issue of September 2002 dossier on WMD. Hutton re-affirmed the view taken by both FAC and ISC that the dossier broadly reflected the JIC material and did not contain deliberate distortions. Not unlike the Scott enquiry of 1996, this investigation was run by a judge with the result that the gathering of evidence was meticulous. However, like Scott, Hutton did not know very much about intelligence. Accordingly, the report written by Lord Hutton was dry and seemed to move past some of the most interesting evidence that he had gathered. Nevertheless, for those who took time to peruse the raw material there were fascinating things to read. Two short examples will serve here.

First, the Hutton enquiry unearthed e-mails that suggested that the more important figures around the Prime Minster were aware that the evidence concerning Iraqi WMD was rather thin. The missing figure here is the Cabinet Secretary, who remains a cypher in the whole affair. However, Hutton did secure an e-mail written by Jonathan Powell, Blair's Chief of Staff, to the Chair of the JIC, John Scarlett. On the eve of publication of the September 2002 dossier, Powell observed:

The document does nothing to demonstrate a threat, let alone an imminent threat, from Saddam. ... . . . We will need to make it clear in launching the document that we do not claim that we have evidence that he is an imminent threat ... if I was Saddam I would take a party of western journalists to the Ibn Sina factory or one of 
the others pictured in the document to demonstrate there is nothing there. How do we close off that avenue to him in advance?

Perhaps more than any other document, this e-mail captures the proactive nature of No.10 Downing Street in the autumn of 2002. ${ }^{38}$

Proactivism was revealed by the Hutton enquiry in a second piece of evidence. Taking evidence from a UN weapons inspector, Scott Ritter, Hutton uncovered an SIS propaganda operation. Whitehall later confirmed that SIS had developed an operation to gain public support for sanctions and the use of military force in Iraq. This was called 'Operation Mass Appeal' and was designed to place stories in the media about Saddam Hussein's nerve gas stocks. ${ }^{39}$ This revelation was especially interesting, given that some observers have long maintained that while the SIS capability for para-military activities is small, much effort is put into information operations. In 2005, Lord Butler also expressed interest in this operation. ${ }^{40}$

More broadly, the Hutton enquiry underlines the manner in which one revelation leads to another. Although, as this essay makes clear, over time much intelligence had been placed in the public domain through 'private channels' and off the record briefings, the dossiers did this more ostentatiously. Once this line had been crossed, the argument could always be made to reveal a little more. Doubtless, those working on the JIC reports and dossiers of 2002 and 2003 had no inkling of just how much would be revealed about UK intelligence by the time the various enquiries had completed their business. Hutton shows us that the placing of intelligence material in the public domain usually leads to the release of further material, perhaps more than one would wish. Individual civil servants were inclined to draw similar, but perhaps more personal conclusions. Intelligence officers and policy advisers alike learned that in the twenty-first century everything is disclosable. Hutton underlined this point by discussing remarkable emails that revealed the casual style of new government in No.10. In 2003 no-one would have dreamed that such material would make its way onto an enquiry website. Perhaps this was a 'e-Gov' of a kind that Whitehall had not really envisaged.

It is hard to resist the notion that the Hutton Enquiry has reinforced the new culture of destruction unleashed by the UK Freedom of Information Act, which was implemented in January 2005. The authorities announced a new era of public transparency, however, this was accompanied by a new private phenomena called 'shredding day'. Up and down the country, civil servants in even the smallest local government offices were urged to trawl their filing cabinets for compromising material and to dispose of it. The Freedom of Information Act is probably a good thing for journalists who want an easy way of chasing issues such as the expense accounts of ministers. It is probably a bad thing for political historians who hope that even sensitive records will eventually be available to us. ${ }^{41}$

\section{The Butler Report on Intelligence and Iraq (Butler)}


Lord Butler's report stated that its remit was to focus on the performance of UK intelligence regarding WMD. In reality it focused on some parts of UK intelligence and not others. It cleared the Defence Intelligence Staff at the Ministry of Defence. It let the JIC off lightly and said nothing about GCHQ or about the interface between intelligence and high policy. It saved most of its fire for SIS, its internal structures and its weak product. Butler, in common with many academic commentators, liked the explanation of 'Groupthink'. It went a long way to offering a genuine explanation of what had happened, but also perhaps allowed his committee to escape pointing the finger at single individuals.

Butler confessed himself to be shocked at the thinness of SIS reporting on Iraq. He could not square the lack of reliable human agent reporting with Blair's confident assertions before Parliament. He stated quite simply that 'SIS did not have agents with first-hand knowledge of Iraq's nuclear, chemical, biological or ballistic missile programmes'. Several of the sources used in 2003 were dismissed as indirect and poor. Some of their reports had to be 'withdrawn' after the war had been launched but this information was not circulated to all the customers. ${ }^{42}$

For almost half a century most personnel within SIS had been divided between two different types of sections. The first type were operational collection or 'production' elements, often organised by region, that recruited spies and gathered intelligence. The second type were the 'requirements' sections which fielded enquires from Whitehall and collated the material for despatch to consumer departments. They were also tasked with evaluating and 'validating' the reliability of the reports. In other words the operational elements produced the goods and the requirements sections provided quality control. ${ }^{43}$

In 1995 this time-honoured system was changed. The UK government was looking for a post-Cold War peace dividend. In reality there was not a lot of peace about and the scale of SIS's tasks were not much diminished. Tracking the diverse conflicts of the new world disorder was, if anything, a harder job. However, modest cuts were called for and so in 1994, SIS underwent a reorganisation in which the requirements sections were combined with the operational or collection elements. This change also reflected the introduction of an intranet distribution system into Whitehall called the UK Intelligence Messaging System. Arguably, the new architecture involved a possible conflict of interest, for the producers were effectively doing more of their own quality control. This should not happen in any well-managed intelligence system. One of Butler's recommendations was to improve quality control and a senior member of SIS has been tasked with implementing changes that flow from the report. ${ }^{44}$

The state of the JIC was also addressed. Butler recommended that in future the chair of the JIC should not be combined with other roles. (In recent times it had sometimes been combined with the role of UK Intelligence Co-ordinator). Moreover, he urged that the incumbent be someone who was used to dealing with, and presumably fending off, ministers and other very senior figures. He suggested this might well be a senior Whitehall official in his last post. In the past the ISC had called for chairs of the JIC to 
be drawn for the intelligence community. Butler's recommendation now reverses that advice. $^{45}$

Even in 2005, the press continued to ask the wrong questions. While Butler was still taking evidence, journalists focused on the selection of John Scarlett, the chairman of the JIC, as the next Chief of SIS, replacing Sir Richard Dearlove. Many argued that the selection of Scarlett was somehow inappropriate. In fact, as an excellent field officer and a succesful former station chief in Moscow, he was the right man for the job. Butler, at least implicitly, was asking a different question. Should John Scarlett, a rising SIS officer in his early forties, have been made chair of the JIC in 2001? In this position he was outranked by much of his own committee, including the chiefs of the three secret services and the two Permanent Under Secretaries. Scarlett's career had not made him an expert in the realm of analysis since no part of SIS does much analysis. In the 1990s, Scarlett has been SIS's Director of Security and Public Affairs. Butler clearly thought that Scarlett was a good intelligence officer, but that this particular appointment had been an odd decision.

Butler also advanced a long-overdue argument for the expansion of the UK Assessments Staff and for the professionalisation of analysis within the UK system. This is not a new point, indeed it was made by Lord Franks in his review of the circumstances leading up to the Falklands War in the 1980s, but Lord Frank's wise suggestion was ignored. ${ }^{46}$ Given that the ISC has been in existence for almost a decade it is somewhat embarrassing that we have had to wait for an ad hoc enquiry to initiate a re-think about the nature and resourcing of assessment. This issue is so important that it is hard to see how the ISC has managed to miss it. The UK spends some 1.5 billion on intelligence, but this material that is so expensively gathered is processed through a machine on which we spend rather little. $^{47}$

Although the JIC is often said to 'produce' JIC reports, this is misleading. In fact the Assessments Staff produce drafts of JIC reports which the committee members then approve, or adjust or send back for redrafting. What is remarkable is that the Assessments Staff is no bigger than it was at its creation in the late 1960s. ${ }^{48}$ This compares with the growth of the Cabinet Office staff as a whole (of which the JIC is part) from approximately 700 to over $2,500 .{ }^{49}$ UK government has always been proud of the JIC and the attendant assessment staff, so much so that it formed a flagship of open government in the 1990s, being described as 'The Central Intelligence Machinery'. ${ }^{50}$ It is all the more surprising then than little has been spent on the supporting staff, perhaps for decades. The culture of the UK intelligence system has always been known for being assessment-lite. So much material is fed relatively raw from the collecting agencies into operational departments, sometimes through deliberate stovepipes. Since 11 September 2001, we have heard - ad nauseam - that CIA has too many analysts and not enough human agents, perhaps the UK intelligence system did not have enough of either. ${ }^{51}$

Butler also expressed the hope that the Assessments Staff would be developed in such a way that it would be able to think 'radically'. However, Butler offered no radical prescriptions. Indeed, he stopped short of adopting calls from previous JIC luminaries for 
the Assessments Staff to include secondees from outside government. ${ }^{52}$ One former JIC chairman, Roderic Braithwaite, had even called for the JIC to be chaired by an outsider, possibly an academic with an international relations background. This is not such a radical idea. In the United States, the most senior intelligence review group, the National Intelligence Committee, has been chaired by Professor Joseph Nye, who was most recently Dean of the Kennedy School of Government at Harvard University. However, these sorts of ideas were given no quarter by Butler and it is safe to assume that 'Groupthink' will continue. ${ }^{53}$

Butler's report is also fascinating for its omissions. Although it claims to be a report into UK intelligence, it mentions Britain's largest and most expensive overseas intelligence gathering agency, GCHQ, only once. The single reference is not an especially revealing one for it occurs in the glossary and explains that GCHQ stands for 'Government Communications Headquarters'. Phrases such as 'signals intelligence' and 'comint' are nowhere to be seen. It is thought that earlier drafts of the Butler report did contain some discussion of signals intelligence but these were removed. What these passages contained is anyone's guess. Some insist that the excellent assistance that the US and the Germans had given to the Iraqi with communications security in the 1980s, especially the installation of fibre-optic cables, rendered much of their communications inaccessible. Others have argued that in a typically authoritarian state, Saddam's underlings were exaggerating what they had achieved in the WMD field and it was this that GCHQ and NSA were picking up. We will wait some time before we know what the sigint story was. However, with this extraordinary omission, the published report (and there is no classified version) cannot really be said to have fulfilled its remit.

Butler passes over some of the most serious issues remarkably lightly. These issues are all about how intelligence connects to the higher echelons of government. Butler notes that the Ministerial Committee on the Intelligence Services (CSI) is the most senior Whitehall committee dealing with intelligence matters. Butler discovered that it had never met in the seven years during which Blair had been in office and recommended that it should meet. However, perhaps what Butler should have said was that in 2001 the ISC had recommended that this committee should meet and Blair ignored them. In 2002 a vexed ISC noted this and 'strongly recommended' that the committee should meet, but again nothing happened in the following year. Blair's remarkable reluctance to join with his ministerial colleagues to discuss intelligence matters tells us a great deal about the way in which intelligence interfaces with the No.10 Downing Street. ${ }^{54}$

The No.10 system is addressed in Butler's concluding paragraphs. This section of the report is perhaps most interesting, but also the most arcanely worded. Here Butler addresses the problem of national security policy made on the sofa. Although expressed in the opaque language of a mandarin, there is an unmistakable dismay at an administration which has abandoned many formal committees and subcommittees, the traditional engine room of British government. Butler's main point was that this lack of process means that much of the wealth of experience and judgement available in the system is not brought to bear on difficult decisions. Moreover, when things go wrong and 
the accountability machine moves in, the paucity of records prevents enquirers from examining how decisions were made. ${ }^{55}$

Butler might have added that this new and informal style at the top was part of the problem for the modern JIC. As we have seen, journalists were quick to suggest that the JIC had somehow been suborned or corrupted. Even the FAC enquiry suggested (wrongly) that Alastair Campbell might have 'chaired' intelligence meetings. Instead, the problem was how a rather traditional piece of intelligence machinery, one that prided itself on procedure and on the delivery of objective facts, was going to adjust to a new style of informal government that preferred subjective policy advice. As early as 1998, some seasoned Whitehall observers had identified that adjusting to the new-style Blair machine was an ongoing problem for the JIC. ${ }^{56}$

Michael Herman, a former secretary of the JIC and also the UK's leading theorist of intelligence, recently reflected on the intelligence lessons that might be drawn from the Cold War. His comments also have a contemporary resonance that may not be entirely unintentional. He observed that one of these lessons was the virtue of keeping a certain distance between intelligence and policy, and even maintaining a certain 'intelligence puritanism' over the precise use made of the JIC's conclusions. He adds, intelligence works for government but its role should really be one of an objective assessor, 'not that of the lawyer whose client wants all the help he can get in pursuing his chosen case'. In making this argument he follows in the tradition of Sherman Kent, who believed that a key role of intelligence was to speak truth to power. ${ }^{57}$

How close, or how distant should the relationship between collectors, analysts and policy-makers be? In the world of the professional intelligence officer this debate has been rumbling on for decades. Although history suggests that mixing up analysts and policy-makers eventually results in problems, this has nevertheless been the long-term trend. ${ }^{58}$ In peacetime, the increasing sophistication of secure online systems has meant that policy makers themselves can access more and more raw material and have tended to become their own analysts. In wartime, the appetite for old fashioned analytical reporting remains immense. ${ }^{59}$ What is clear is that the cultural context of intelligence has changed rapidly in the last few years. Since 9/11, policy-makers have used convenient arguments about new situations and 'new threats' to sweep away old conventions which they found irksome or restrictive, but which nevertheless reflected lessons hard-learned over decades. $^{60}$ Press advisers and publicity people from No.10 may not have chaired intelligence meetings, but they certainly attended meetings of the JIC. Had anyone ever suggested this possibility to Percy Cradock, one-time chairman and stalwart of the JIC system in the 1980s, there would have been an audible explosion. ${ }^{61}$ 
* The author would like to acknowledge the support of a Leverhulme Fellowship which facilitated the research for this paper.

$1 \quad$ Loch K. Johnson, A Season of Inquiry: The Senate Intelligence Investigation (University Press of Kentucky, 1985).

2 Much has already been written about the four enquiries. See in particular, A. Danchev, The Reckoning: Official Inquiries and the Iraq War', Intelligence and National Security, Vol.19, No.3 (Autumn 2004); M. Herman, 'Intelligence and the Iraqi Threat: British Joint Intelligence after Butler', JRUSI, Vol.149, No.4, (August 2004): 18-24. The Hutton enquiry has been subjected to detailed analysis in A. Glees \& P. H.J. Davies, Spinning the Spies: Intelligence, Open Government and the Hutton Enquiry (London: The Social Affairs Unit, 2004). Butler has been analysed by I. Davis and A. Persho in 'After the Butler Report: Time to Take on the Group Think in Washington and London', BASIC papers: Occasional Papers in International Security, (July 2004), No.40. Peter Gill's paper to a conference in Oslo, 'Intelligence Oversight Since 9/11: Information Control and the Invasion of Iraq', is available at http://www.dcaf.ch/news/Intel\%20Acct_Oslo\%200903/Gill.pdf

$3 \quad$ Herman, 'Intelligence and the Iraqi Threat', p. 18.

$4 \quad$ The French DGSE took a contrary view and as early as 2002 declared the Iraqi WMD threat to be a myth, see 'French Intelligence Service Assesses Iraqi War Potential,' FBIS, Sept 25, 2002. The Dutch are also thought to have been somewhat sceptical.

$5 \quad$ Leaked documents suggest that the date at which war seemed certain now appears to have been 23 July 2002, M. Smith, 'Blair Planned Iraq War From Start', 1 May 2005, Sunday Times.

$6 \quad$ The issue of the date at which the allies knew that the United States had decided on war is emphasised in Wilkie, Axis of Deceit (Melbourne: Black Inc, 2004). A number of special forces operations seem to have been launched into Iraq before the deadline expired.

The only SIS officer to have departed and to have been named is Mark Allen. Richard Norton-Taylor, 'Another top MI6 officer quits', Guardian, 6 December 2004. Private information.

$8 \quad$ HC 813-I, House of Commons Select Committee on Foreign Affairs, The Decision to go to War with Iraq, Ninth Report of the Session 2002-3, Volume 1, 3 July 2003.

$9 \quad$ For example HC 384, Foreign Policy Aspects of the War Against Terrorism, paras.11-22.

$10 \quad$ HC 813-I, The Decision to go to War with Iraq, p.7, para. 3.

11 'Groupthink' is most fully discussed in I. Davis and A. Persho, 'After the Butler Report:

Time to Take on Group Think'. The concept was invented by Janis Irving, Victims of Groupthink. Boston: Houghton Mifflin, 1972). See also J. Irving, Groupthink: Psychological studies of policy decisions and fiascos. (2nd ed. Boston: Houghton Mifflin, 1982).

12 HC 813-I, The Decision to go to War with Iraq, p.29, paras. 84-6.

13 HC 813-I, The Decision to go to War with Iraq, p.9, para. 8. However, opinion varies as to the extent to which IISS has drawn on informal assistance from Whitehall in preparing its some of its estimates.

14 HC 813-I, The Decision to go to War with Iraq, p.9, para. 10

15 ISC concluded that by 1995 UNMOVIC inspections had revealed Iraqi's pre-1991 nuclear programme to have been more advanced than the UK JIC had thought. Cm 5972, Intelligence and Security Committee, Iraq Weapons of Mass Destruction - Intelligence and Assessments, (hereafter Cm 5972, ISC, Iraq Weapons) 9 September 2003, p.14 para. 35.

16 CIC dossier, Iraq - Its Infrastructure Of Concealment, Deception And Intimidation, February 2003. 
17 Other material was taken from articles in Jane's Intelligence Review. For a full analysis see the evidence submitted to FAC by Dr Glen Rengwala of Cambridge University at http://middleeastreference.org.uk/fac030616.html

18 HC 813-I, The Decision to go to War with Iraq, p.5, conclusion 8.

19 HC 813-I, The Decision to go to War with Iraq, p.39, para. 125. Although the ISC has since made public the SIS contribution to this dossier, the material on supporting terrorist organisations does not seem to have come from SIS either.

20 Perhaps the worst tactical blunder committed by No.10 was to lay themselves open to some freelance intelligence work by academics. The February 2003 dossier was placed on the No.10 website as a Word file. Officials had failed to remove the metadata from the file, which included a log of the last 10 changes UK government and indeed other government have at least learned this lesson, and have since moved to making documents available as PDF files which do not retain such data. 'The Key Backroom Players', Evening Standard, 25 June 2003.

21 On IRD see P. Lashmar and J. Oliver, Britain's Secret Propaganda War (London: Sutton, 1998). On Information Policy see P. Foot, Who Framed Colin Wallace (London: Macmillan, 1989).

22 SIS reportedly made material available to Gordon Brooke-Shepherd for The Storm Petrels: The First Soviet Defectors, 1928-1938 (New York: Harcourt and Brace, 1978), and more recently for The Iron Maze The Western Secret Services and the Bolsheviks (Macmillan, London, 1998).

23 Regarding ICTY, Robin Cook stated that he had given assurances to the Tribunal 'that we will provide them with all our intelligence', adding that it was a 'quite a remarkable and unique step' for a government to show its intelligence to an international court. Exactly what sort of material was eventually provided remains a matter of debate. House of Commons, Foreign Affairs Committee, minutes of evidence, 28 April 1999, question 186.

$24 \quad$ Private information.

25 For JIC excerpts see for example HC 898, Review of Intelligence on Weapons of Mass Destruction, 14 July 2004, (hereafter HC 898 Butler), Annex B, 'Intelligence Assessments and Presentation: From March to September 2002', p.163.

$26 \quad$ G. Drewry (ed.), The New Select Committees (Oxford: Clarendon 1989).

$27 \quad$ HC 813-I, The Decision to go to War with Iraq, p.8, para 6.

$28 \quad$ Members of Parliament in the UK have frequently called for accountability to be focused on the select committee model. Typically, in June 1999 the chairman of the Home Affairs select committee, Labour MP Chris Mullin, called for reform of ISC, arguing that its reconstitution as a new select committee on intelligence would have the power to 'summon witnesses and to obtain papers'. It would also be appointed by Parliament and not the prime minister. BBC News, 22 June 1999, 'Spies Need Scrutiny', http://news.bbc.co.uk/1/low/uk_politics/374764.stm

$29 \quad$ Ibid. p.49, para.165. See also Danchev, 'The Reckoning', pp.436-7.

$30 \quad$ On ISC generally see: P. Gill, 'Reasserting Control: recent changes in the oversight of the UK intelligence community,' Intelligence and National Security, Vol.11, No.2, (1996), 313-31.

31 Cm 5972, ISC, Iraq Weapons, paras 106-8.

32 The committee concluded that this area involved striking a 'difficult balance' and required 'further thought' , Cm 6510, ISC, Annual Report 2004-5, April 2005, p.31, para.88.

33 Cm 5972, ISC, Iraq Weapons, page 48, conclusion $\mathrm{N}$.

$34 \quad$ JIC (48) 9 (0), Russian Interests, Intentions and capabilities', 23 July 1948, L/WS/1/1173, India Office War Staff records, British Library. Under both biological and chemical weapons the JIC noted 'we have no knowledge' but 'must assume'.

35 Cm 5972, ISC, Iraq Weapons, Annex B, ISC Comments on Foreign Affairs Committee Report, p.56. 
36 It is now clear that there was extensive pooling of allied intelligence in this area, not least at an annual WMD intelligence conference lasting a week for about fifty specialists from UK, USA and Australia, see Wilkie, Axis, 91-2.

37 HC 384, Seventh Report from the Foreign Affairs Committee, Session 2001-02, Foreign Policy Aspects of the War against Terrorism, Q 292.

38 E-mail from Jonathan Powell to John Scarlett, 17 September 2002, CAB/11/69, Hutton enquiry evidence.

39 Nicholas Rufford, 'Revealed: How MI6 Sold The Iraq War', Sunday Times, 28 December 2003.

40 HC 898, Butler, p.120, para.485.

41 R. Allen, 'Whitehall shredding files before they have to be disclosed', Times, 23 December 2004; S. Laville, 'Livingstone faces Shredding Enquiry, Guardian, 22 March 2005.

$42 \quad$ HC 898, Butler, p.105, para.436.

43 The most detailed analysis is offered in P. Davies, 'MI6's Requirements Directorate: Integrating Intelligence into the Machinery of British Central Government', Public Administration, Vol. 78, No.1 (Spring 2000): 29-49. See also P. Davies, MI6 and the Machinery of Spying (London: Frank Cass, 2004).

${ }_{44}$ HC 898, Butler, pp.99-103, paras.398-423. I am also indebted to Philip Davies for his comments on this matter.

$45 \quad$ HC 898, Butler, pp.143-4, paras. 591-7.

46 A. Danchev (ed.), The Franks Report (London: Pimlico, 1992).

$47 \quad$ HC 898, Butler, p.144, paras. 598-601.

48 Herman, 'Intelligence and the Iraqi Threat', p. 18.

49 Civil Service Statistics (London: HMSO, 1970), p.20, Table 5; DEFRA, Sustainable Development The Government's approach - delivering UK sustainable development together, 7 March 2005.

50 Central Intelligence Machinery (London: Cabinet Office 1996)

$51 \quad$ David Omand, the Security and Intelligence Coordinator has set up the Butler Implementations Group (BIG) to oversee the required changes. Cm 6510, ISC, Annual Report 2004-5, p.31. para.66.

$52 \quad$ Herman, 'Intelligence and the Iraqi Threat', p. 22.

$53 \quad$ Glees \& Davies, Spinning the Spies, p.96.

$54 \quad$ Cm 5542, ISC, Annual Report 2001-2, 8 May 2002, p.7, para.10. Parts of this are reminiscent of the manner in which Nixon and Kissinger re-arranged the US NSC architecture in 1970.

$55 \quad$ HC 898, Butler, p.148, para.611

$56 \quad$ P. Hennessy, British Prime Ministers Since 1945 (London: Allen Lane, 1999), pp. 501-2.

57 M. Herman, 'Threat Assessment and the Legitimation of Policy?', Intelligence and National Security, Vol.18, No.3 (Autumn 2003), p.178.

58 J. Wirtz, 'Intelligence to Please? The Order of Battle Controversy during the Vietnam War', Political Science Quarterly Vol.106, No. 2 (Summer 1991): 239-263.

59 C. Medina, 'The Coming Revolution in Intelligence Analysis: What To Do When Traditional Models Fail', Studies in Intelligence, Vol.46, No.3 (2000); S.R. Ward, 'Evolution Beats Revolution in Analysis', ibid.

$60 \quad$ On the forgetting of history, see C.M. Andrew, 'Intelligence Analysis Needs to Look Backwards Before Looking Forward Why lessons of the past can help fight terror of the future', June 2004, http://ctstudies.com/index.html

61 Cradock's classic account of the JIC is Know Your Enemy: How the Joint Intelligence Committee Saw the World (London: John Murray, 2002). 